\title{
Development of Soil Test based Fertilizer Prescription Equations under IPNS for Rice in Salt affected soils of Tamil Nadu
}

\author{
Sherene Jenita Rajammal ${ }^{1}$, T, S. Maragatham ${ }^{2}$ and R.Santhi ${ }^{3}$ \\ ${ }^{\text {I}}$ Tamil Nadu Agricultural University, Anbil Dharmalingam Agricultural College and \\ Research Institute, Tiruchirapalli, Tamil Nadu, India \\ ${ }^{2 \& 3}$ Tamil Nadu Agricultural University, Coimbatore, Tamil Nadu, India \\ ${ }^{1}$ shereneraj@yahoo.co.in, 22s_marags@yahoo.com, ${ }^{3}$ santhitnau@yahoo.com
}

\begin{abstract}
Soil Test Crop Response - Integrated Plant Nutrition System (STCR - IPNS) technology in restoring soil fertility in sodic soil was well established in this study. STCR -IPNS correlation studies were conducted with rice in black calcareous sandy clay loam (Vertic Ustropept) sodic soils of Tamil Nadu, Southern India during 2019 - 2021and fertilizer prescription equations under Integrated Plant Nutrition System (IPNS) were developed. A ready reckoner of fertilizer doses at varying soil test values, for attaining 6 and $6.5 \mathrm{tha}$-I target grain yield of rice has been worked out. Using these equations, test verification trials were conducted on farmer's holding in Manikandam block of Tiruchirapalli district. The per cent achievement of the targets aimed was more than 90 indicating the validity of the equations for prescribing fertilizer doses for rice under sodic soils. The STCR -IPNS treatments recorded relatively higher response ratio (RR) and benefit - cost ratio (BCR) over blanket, STCR - NPK alone treatments and farmer's practice. Post-harvest soil tests for NPK revealed that there was maintenance of soil fertility under sodic soil.
\end{abstract}

Keywords: Sodic soil, Fertilizer prescription equations, STCR-IPNS,

\section{Introduction}

Nearly 7.0 million ha of agricultural land is affected by varying degrees of salt problems in the country. The affected area is likely to increase in the near future due to secondary salinization in irrigation commands and lift irrigated schemes, increase in dependence of agriculture on poor quality waters in semi-arid and arid regions, sea water intrusion and brackish water aquaculture in coastal regions. By 2025 area projected under salt affected soils in India is about 13 million ha. In Tiruchirappalli district, out of the total geographical area of 4,40,412 ha, 7,362 ha are slightly salt affected ( $\mathrm{pH} 8.2$ to $9.0), 10,729$ ha are moderately salt affected ( $\mathrm{pH} 9.0$ to 9.6) and 64 ha are strongly salt affected $(\mathrm{pH}>10)$. 
Alkali or sodic soil is defined as a soil having a conductivity of the saturation extract less than $4 \mathrm{dS} \mathrm{m}^{-1}$ and an exchangeable sodium percentage greater than 15 . The $\mathrm{pH}$ is usually between $8.5-10.0$. Most alkali soils, particularly in the arid and semi-arid regions, contain $\mathrm{CaCO}_{3}$ in the profile in some form and constant hydrolysis of $\mathrm{CaCO}_{3}$ sustains the release of $\mathrm{OH}^{-}$ions in soil solution. The $\mathrm{OH}^{-}$ions so released result in the maintenance of higher $\mathrm{pH}$ in calcareous alkali soils than that in non - calcareous alkali soils.Sodic soils are inherently low in organic matter $(<0.1 \%)$, and available $\mathrm{N}$, and are more responsive to $\mathrm{N}$ application. These soils are more prone to $\mathrm{N}$ losses due to higher $\mathrm{N}$ volatilization caused by high $\mathrm{pH}$, further aggravating $\mathrm{N}$ deficiency.

Grain yield of rice in salt affected soils is much lower because of its high sensitivity to salt stress (Ajay kumar et al.2016). Rice is exceptionally sensitive to salinity and sodicity at early seedling stage (Anjali et al., 2015) and high yield losses have been observed because of high mortality and poor crop establishment. Modern high yielding varieties require considerable investment to ameliorate these soils to ensure reasonable yields, but this investment is beyond the capabilities of the resource-limited small holder farmers living off these salt affected areas. Plant mortality in sodic soils is high when young seedlings are transplanted, adversely affecting plant establishment and growth.

Among the various methods of formulating fertilizer recommendations, the one based on yield targeting is unique in the sense that this method not only indicates soil test based fertilizer dose but also the level of yield the farmer can hope to achieve, if good cultivation package is followed (Ramamoorthy and Velayutham, 2011). In the "Inductive Approach" of STCR field experimentation, all the needed variation in soil fertility level is obtained not by selecting soils at different locations as in earlier agronomic trials, but by deliberately creating it in one and the same field experiment in order to reduce heterogeneity in the soil population (types and units) studied, management practices adopted and climatic conditions. Ramamoorthy et al., (1967) have elaborated this Inductive approach and the STCR field design. The experimental data can be used for developing fertilizer recommendations for maximum yield and profit and for desired yield targets of crops. The fertilizer prescription equations developed using this model can be applied to sodic Vertisols of all tropical regions by substituting the soil nutrient status of the particular field for rice crop.On account of the above facts, the present investigation was contemplated in rice on Vertisol under sodic soil so as to elucidate the significant relationship between soil test values and crop response to fertilizers, to develop fertilizer prescription equations under IPNS for desired yield target of rice under sodic soil.

\section{Materials and methods}

The field experiment was conducted in typical sodic soils of Agriculture college farm, Tiruchirapalli, Tamil Nadu, Southern India. The farm is located in the Cauvery Delta Zone of Tamil Nadu at $10^{\circ} 15^{\prime}$ and $11^{\circ} 2^{\prime} \mathrm{N}$ latitude and $78^{\circ} 10^{\prime}$ to $79^{\circ} 5^{\prime} \mathrm{E}$ 
longitude at an altitude of $90 \mathrm{~m}$ above MSL. The experiment was conducted during October 2019 to March 2020. The soil of the experimental field belongs to Allathur soil series taxonomically referred as Vertic Ustropept, hyper thermic family of sodic Natrustalf exhibiting sandy loam texture, alkaline reaction ( $\mathrm{pH} 9.02)$ and non - saline conditions (EC $1.15 \mathrm{dS} \mathrm{m}^{-1}$ ) and exchangeable sodium percentage (ESP) of 51.23 (Table.1). Making use of data on the yield of paddy, total uptake of N, P and K, initial soil test values for available $\mathrm{N}, \mathrm{P}$ and $\mathrm{K}$ and doses of fertilizer $\mathrm{N}, \mathrm{P}_{2} \mathrm{O}_{5}$ and $\mathrm{K}_{2} \mathrm{O}$ applied, the basic parameters viz., nutrient requirement (NR), contribution of nutrients from soil (Cs), fertilizer (Cf) and farmyard manure (Cfym) were calculated as outlined by Ramamoorthy et al. (1967). To suggest soil test based balanced fertilization for rice under sodic soil, fertilizer prescription equations under IPNS were developed for sodic Vertisols (Typic Ustropepts) of Tirichirapalli district during 2019-2021 following the Inductive cum Targeted yield model.

Table 1. Initial soil characteristics of the experimental field

\begin{tabular}{|l|l|}
\hline Soil $\mathrm{pH}$ & 9.02 \\
\hline Soil EC $\left(\mathrm{dSm}{ }^{-1}\right)$ & 1.15 \\
\hline Soil Texture & Sandy loam \\
\hline Organic carbon $(\%)$ & 0.41 \\
\hline Available $-\mathrm{N}\left(\mathrm{kg} \mathrm{ha}^{-1}\right)$ & 224 \\
\hline Available $-\mathrm{P}\left(\mathrm{kg} \mathrm{ha}^{-1}\right)$ & 22.7 \\
\hline Available $-\mathrm{K}\left(\mathrm{kg} \mathrm{ha}^{-1}\right)$ & 249.7 \\
\hline Cation Exchange Capacity (c.mol (p+) $\mathrm{kg}^{-1}$ & 27.4 \\
\hline Exchangable Sodium (m.eq/100 g of soil) & 14.45 \\
\hline Exchangable Sodium Percentage (ESP) & 52.73 \\
\hline
\end{tabular}

These equations were test verified with a view to demonstrate the validity of fertilizer prescription equations under IPNS developed for Rice in sodic Vertisols of Trichirapalli district by conducting verification trials in farmer's fields and to suggest the target yield that gives the highest Benefit Cost Ratio (BCR) and Response Ratio (RR) to the farmers in that region. There were eight treatments viz., $\mathrm{T}_{1}-$ Blanket (RDF alone), $\mathrm{T}_{2}$ - Blanket (RDF+ FYM @ $12.5 \mathrm{t} \mathrm{ha}^{-1}$ ), $\mathrm{T}_{3}$ - STCR-NPK alone- $5 \mathrm{t} \mathrm{ha}^{-1}, \mathrm{~T}_{4}-\mathrm{STCR}-\mathrm{NPK}$ alone - $6 \mathrm{t} \mathrm{ha}^{-1}, \mathrm{~T}_{5}-\mathrm{STCR}-$ IPNS - $5 \mathrm{t} \mathrm{ha}^{-1}, \mathrm{~T}_{6}-\mathrm{STCR}-$ IPNS $-6 \mathrm{t} \mathrm{ha}^{-1}, \mathrm{~T}_{7}$ - Farmer's Practice and $\mathrm{T}_{8}-$ absolute control. Initial soil samples were collected and analysed for available $\mathrm{N}, \mathrm{P}$ and $\mathrm{K}$. Based on the initial soil test values of available $\mathrm{N}, \mathrm{P}_{2} \mathrm{O}_{5}, \mathrm{~K}_{2} \mathrm{O}$ and yield targets aimed, fertilizer doses were calculated and applied for STCR treatments. For IPNS treatments, 12.5 tonnes of FYM were applied basally and fertilizer $\mathrm{N}, \mathrm{P}_{2} \mathrm{O}_{5}$, $\mathrm{K}_{2} \mathrm{O}$ doses were adjusted accordingly.

Plot wise grain and straw yield were recorded. Soil samples were collected and analysed for available N, P and K. The details of fertilizer doses applied, grain yield, percentage achievement and response ratio are furnished in Table.1 .Using the data on 
grain yield, fertilizer doses applied and cost of fertilizer inputs and produce, the parameters viz., Response Ratio (RR) and Benefit -Cost Ratio (BCR) were worked out (Response Ratio=Response in $\mathrm{kg}$ ha-1/Quantities of fertiliser $\mathrm{N}, \mathrm{P}_{2} \mathrm{O}_{5}$ and $\mathrm{K}_{2} \mathrm{O}$ applied in $\mathrm{kg} \mathrm{ha}^{-\mathrm{I}}$ Benefit-Cost Ratio=Cost of additional seed yield over control/Cost of fertiliser $\mathrm{N}, \mathrm{P}_{2} \mathrm{O} 5$ and $\mathrm{K}_{2} \mathrm{O}$ applied). Post-harvest soil samples were also collected and analysed for available $\mathrm{N}$, available $\mathrm{P}$ and available $\mathrm{K}$.

\section{Results and discussion}

\section{Response of rice to fertilizer nutrients}

Response of rice to different doses of fertiliser $\mathrm{N}, \mathrm{P}_{2} \mathrm{O}_{5}$ and $\mathrm{K}_{2} \mathrm{O}$ was assessed. The response varied from $843 \mathrm{~kg} \mathrm{ha}^{-1}$ in FYM @ $6.25 \mathrm{t} \mathrm{ha}^{-1}$ to $2933 \mathrm{~kg}$ in STCR-IPNS$6.5 \mathrm{t} \mathrm{ha}^{-1}$. The data showed that irrespective of STCR-NPK alone or STCR-IPNS, there was a progressive increase in response from lower target to higher targets and the magnitude of response was higher under STCR-IPNS than under STCR-NPK alone treatments (Table 2).

Table 2. Response of rice as influenced by various treatments under sodic soil

\begin{tabular}{|c|c|c|c|c|c|}
\hline \multirow{2}{*}{ Treatments } & \multicolumn{3}{|c|}{ tiliser doses $\left(\mathrm{kg} \mathrm{ha}^{-1}\right)$} & \multicolumn{2}{|c|}{$\begin{array}{l}\text { Mean } \\
\text { grain YieldResponse }\end{array}$} \\
\hline & FN & $\mathrm{FP}_{2} \mathrm{O}_{5}$ & $\mathrm{FK}_{2} \mathrm{O}$ & $\left(\mathrm{kg} \mathrm{ha}^{-1}\right)$ & $\left(\mathrm{kg} \mathrm{ha}^{-1}\right)$ \\
\hline \begin{tabular}{l|l}
1 & STCR- NPK alone $-5.5 \mathrm{tha}^{-1}$
\end{tabular} & 144 & 63 & 73 & 4878 & 2245 \\
\hline 2 STCR- NPK alone $-6.0 \mathrm{tha}^{-1}$ & 170 & 72 & $75 * *$ & 5123 & 2490 \\
\hline 3 STCR - NPK alone $-6.5 \mathrm{t} \mathrm{ha}^{-1}$ & 197 & $75 * *$ & $75 * *$ & 5390 & 2757 \\
\hline \begin{tabular}{l|l}
4 & STCR - IPNS - 5.5 t ha \\
\end{tabular} & 116 & 45 & $25^{*}$ & 5144 & 2511 \\
\hline \begin{tabular}{l|l}
5 & STCR - IPNS $-6.0 \mathrm{t} \mathrm{ha}^{-1}$
\end{tabular} & 143 & 54 & 35 & 5371 & 2738 \\
\hline \begin{tabular}{l|l}
6 & STCR - IPNS - 6.5 t ha \\
\end{tabular} & 170 & 64 & 49 & 5566 & 2933 \\
\hline 7 FYM alone @ $6.25 \mathrm{t} \mathrm{ha}^{-1}$ & 23 & 10 & 21 & 3476 & 843 \\
\hline \begin{tabular}{l|l}
8 & FYM alone @ $12.5 \mathrm{tha}^{-1}$
\end{tabular} & 46 & 19 & 42 & 3987 & 1354 \\
\hline 9 Absolute control & 0 & 0 & 0 & 2633 & 0 \\
\hline
\end{tabular}

\section{Basic parameters}

Using the data on the grain yield, total uptake of $\mathrm{N}, \mathrm{P}$ and $\mathrm{K}$, initial soil test values for available $\mathrm{N}, \mathrm{P}$ and $\mathrm{K}$ and doses of fertilizer $\mathrm{N}, \mathrm{P}_{2} \mathrm{O}_{5}, \mathrm{~K}_{2} \mathrm{O}$ and FYM applied, the basic parameters viz., nutrient requirement (NR), contribution of nutrients from soil (Cs), fertilizer (Cf) and farmyard manure (Cfym) were computed (Table 3). 
Table 3. Basic parameters

\begin{tabular}{|l|c|c|c|}
\hline \multirow{2}{*}{ Parameters } & \multicolumn{3}{|l|}{ Basic data } \\
\cline { 2 - 4 } & $\mathbf{N}$ & $\mathbf{P}_{\mathbf{2}} \mathbf{O}_{\mathbf{5}}$ & $\mathbf{K}_{\mathbf{2}} \mathbf{O}$ \\
\hline Nutrient requirement $\left(\mathrm{kg} \mathrm{q}^{-1}\right)$ & 1.44 & 0.29 & 1.76 \\
\hline Per cent contribution from soil (Cs) & 17.18 & 28.14 & 23.42 \\
\hline Per cent contribution from fertilizers (Cf) & 23.71 & 18.2 & 59.4 \\
\hline Per cent contribution from FYM (Cfym) & 18.89 & 12.56 & 43.59 \\
\hline
\end{tabular}

This formed the basis to compute the basic parameters and develop the fertilizer prescription equations under IPNS for rice under sodic soil. The results emanated from the present investigation revealed that rice requires $1.44 \mathrm{~kg} \mathrm{~N}, 0.29 \mathrm{~kg} \mathrm{P}_{2} \mathrm{O}_{5}$ and $1.76 \mathrm{~kg}$ $\mathrm{K}_{2} \mathrm{O}$ for producing one quintal of grain yield.

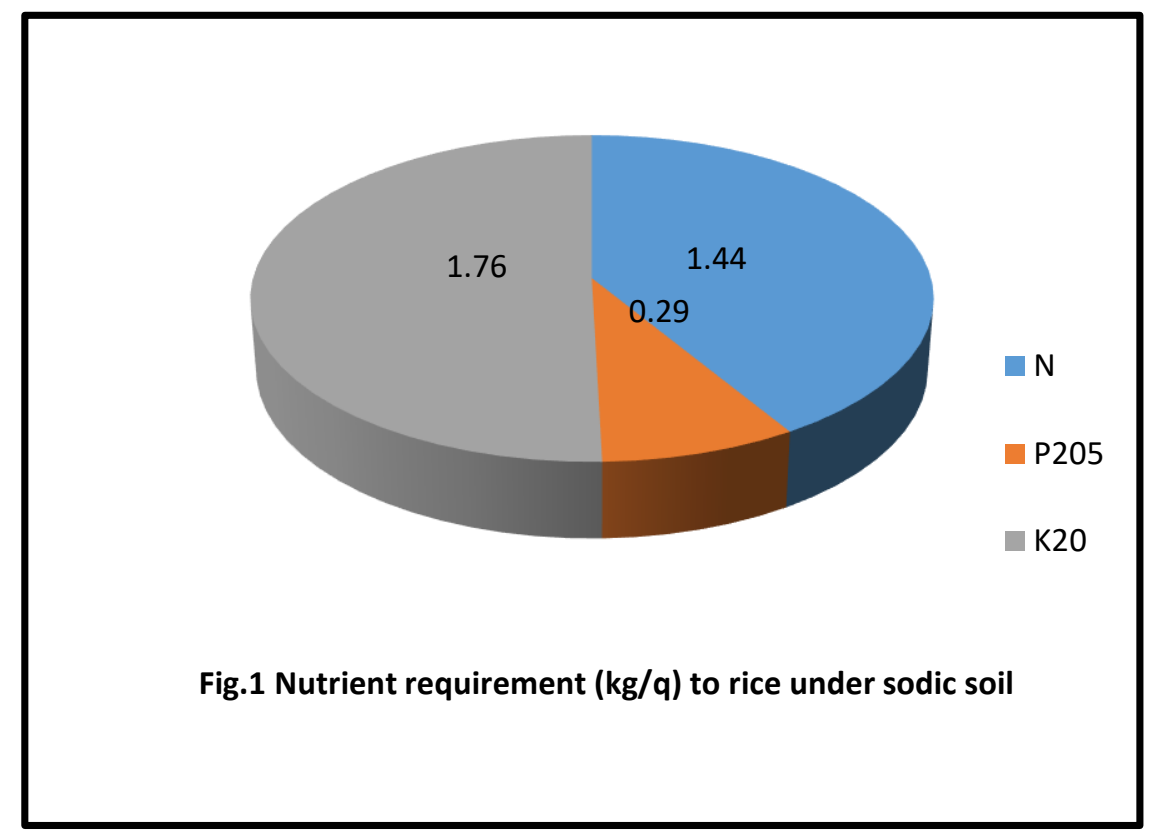

The per cent contribution of $\mathrm{N}$ from soil was 17.18 and fertilizer was 23.71. With regard to $\mathrm{P}_{2} \mathrm{O}_{5}$, the percent contribution from soil was 28.14 and fertilizer was 18.2 while for $\mathrm{K}_{2} \mathrm{O}$, the percent contribution from soil was 23.42 and from fertilizer was 59.4 percent. The percent contribution of nutrients from FYM was 18.89, 12.56 and 43.59 per cent $\mathrm{N}$, $\mathrm{P}_{2} \mathrm{O}_{5}$ and $\mathrm{K}_{2} \mathrm{O}$ respectively. 

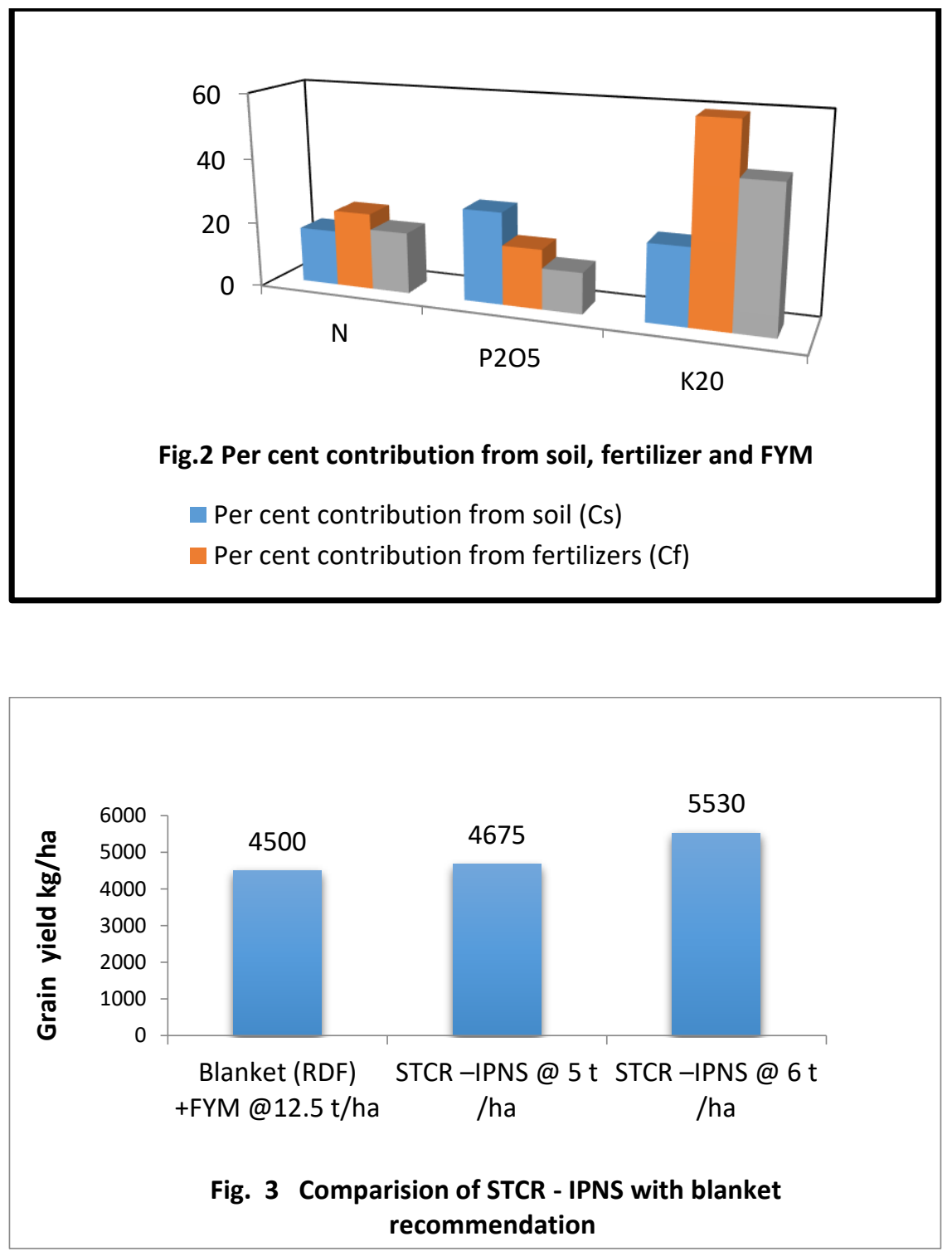

\section{Fertilizer Prescription Equations for rice under sodic soils}

Making use of the basic parameters viz., NR, Cs, Cf and Cfym, the Fertiliser Prescription Equations were developed under NPK alone and IPNS.

\begin{tabular}{l|l}
\hline STCR-NPK alone & STCR-IPNS (NPK+FYM) \\
\hline $\mathrm{FN}=6.08 \mathrm{~T}-0.72 \mathrm{SN}$ & $\mathrm{FN}=6.08 \mathrm{~T}-0.72 \mathrm{SN}-0.80 \mathrm{ON}$ \\
$\mathrm{FP}_{2} \mathrm{O}_{5}=1.64 \mathrm{~T}-1.55 \mathrm{SP}$ & $\mathrm{FP}_{2} \mathrm{O}_{5}=1.64 \mathrm{~T}-1.55 \mathrm{SP}-0.69 \mathrm{OP}$ \\
$\mathrm{FK}_{2} \mathrm{O}=2.96 \mathrm{~T}-0.39 \mathrm{SK}$ & $\mathrm{FK}_{2} \mathrm{O}=2.96 \mathrm{~T}-0.39 \mathrm{SK}-0.73 \mathrm{OK}$ \\
\hline
\end{tabular}

where, $\mathrm{FN}, \mathrm{FP}_{2} \mathrm{O}_{5}$ and $\mathrm{FK}_{2} \mathrm{O}$ are fertilizer $\mathrm{N}, \mathrm{P}_{2} \mathrm{O}_{5}$ and $\mathrm{K}_{2} \mathrm{O}$ in $\mathrm{kg} \mathrm{ha}^{-1}$, respectively; $\mathrm{T}$ is the grain yield target in $\mathrm{q} \mathrm{ha}^{-1}$ and $\mathrm{SN}$, SP and SK respectively are alkaline $\mathrm{KMnO}_{4}-$ $\mathrm{N}, \mathrm{Olsen}-\mathrm{P}$ and $\mathrm{NH}_{4} \mathrm{OAc}-\mathrm{K}$ in $\mathrm{kg} \mathrm{ha}^{-1}$; ON, OP and $\mathrm{OK}$ are quantities of $\mathrm{N}, \mathrm{P}$ and $\mathrm{K}$ in $\mathrm{Kg} \mathrm{ha}^{-1}$ supplied through FYM. 


\section{Soil test based fertilizer recommendations for various yield targets of rice under sodic soil}

Ready reckoner of fertilizer doses (nomograms) were formulated for desired yield targets of rice for a range of soil test values under IPNS (NPK plus FYM @ $12.5 \mathrm{t}$ $\left.\mathrm{ha}^{-1}\right)$. Using the fertilizer prescription equations under IPNS, the extent of saving of inorganic fertilizers was computed. The results showed that with the application of FYM @ $12.5 \mathrm{t} \mathrm{ha}^{-1}$ (with $30 \%$ moisture, $0.60 \%, 0.30 \%$ and $0.5 \%$ NPK respectively), there was a saving of 42,18 and $32 \mathrm{~kg}$ of fertilizer $\mathrm{N}, \mathrm{P}_{2} \mathrm{O}_{5}$ and $\mathrm{K}_{2} \mathrm{O}$ respectively.

A perusal of the estimate showed that when NPK alone were applied, for a soil test value of $180 \mathrm{~kg} \mathrm{KMnO}_{4}-\mathrm{N} \mathrm{ha}^{-1}$, the doses of fertilizer $\mathrm{N}$ required for desired yield targets of 5.5, 6.0 and $6.5 \mathrm{t} \mathrm{ha}^{-1}$ were 204, 235 and $265 \mathrm{~kg} \mathrm{ha}^{-1}$, respectively. When FYM @ 12.5 $\mathrm{t} \mathrm{ha}^{-1}$ was applied along with NPK, the required fertilizer $\mathrm{N}$ doses were 162, 193 and 223 $\mathrm{kg} \mathrm{ha}^{-1}$ with 20.58, 17.87 and 15.84 per cent reduction in fertilizer doses over NPK alone respectively for the same yield target and soil test values. In case of $\mathrm{P}$ fertilization, when NPK alone were applied, for a soil test value of $18 \mathrm{~kg} \mathrm{ha}^{-1}$ of Olsen-P, the doses of fertilizer $\mathrm{P}_{2} \mathrm{O}_{5}$ required for desired yield targets of 5.5, 6.0 and $6.5 \mathrm{t} \mathrm{ha}^{-1}$ were 62, 70 and $78 \mathrm{~kg} \mathrm{ha}^{-1}$ respectively. When NPK were applied along with FYM @ $12.5 \mathrm{t} \mathrm{ha}^{-1}$, the doses were 44, 52 and $60 \mathrm{~kg} \mathrm{ha}^{-1}$ with a per cent reduction of 29.03, 25.71 and 23.07 respectively over NPK alone (Bagavathi Ammal et al. (2013). With regard to fertilizer $\mathrm{K}_{2} \mathrm{O}$ doses, it was found that to achieve the desired yield targets of 5.5, 6.0 and $6.5 \mathrm{t} \mathrm{ha}^{-1}$, for a soil test value of $200 \mathrm{~kg} \mathrm{NH} 4 \mathrm{OAc}-\mathrm{K}$, the fertilizer $\mathrm{K}_{2} \mathrm{O}$ requirements were 84, 99 and $114 \mathrm{~kg} \mathrm{ha}^{-1}$, respectively. When NPK were applied with FYM @ $12.5 \mathrm{t} \mathrm{ha}^{-1}$, the $\mathrm{K}_{2} \mathrm{O}$ doses were 52,67 and $82 \mathrm{~kg} \mathrm{ha}^{-1}$ with a percent reduction of 38.09, 32.32 and 28.07 over NPK alone respectively (Table 4).

\section{Table 4. Soil test based fertilizer recommendations for various yield targets} of rice under sodic soil

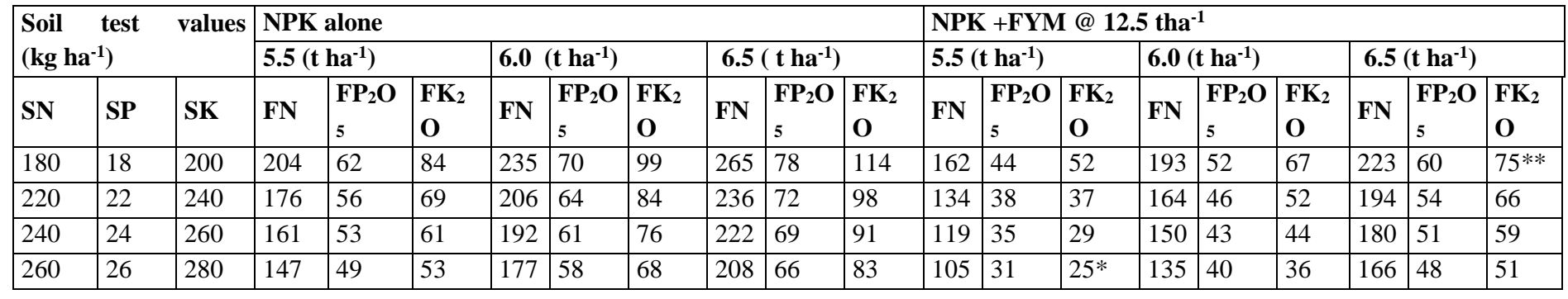

$\mathrm{NB}: *$ maintenance dose. $* *$ maximum dose Blanket dose: $187.5: 50: 50 \mathrm{~kg} \mathrm{ha}^{-1}$ of fertilizer $\mathrm{N}, \mathrm{P}_{2} \mathrm{O}_{5} \& \mathrm{~K}_{2} \mathrm{O}$ respectively for rice Note: When FYM@ $12.5 \mathrm{t} \mathrm{ha}^{-1}$ with $0.6,0.30,0.5$ and $30 \%$ of moisture, N, P and K, respectively is applied 42,18 and $32 \mathrm{~kg}$ of $\mathrm{N}, \mathrm{P}_{2} \mathrm{O}_{5}$ and $\mathrm{K}_{2} \mathrm{O}$ ha $^{-1}$ could be reduced from the recommended dose of fertilizer; $12 \mathrm{~kg}$ ha-i of fertilizer $\mathrm{N}$ could be reduced when Azospirillum is applied @ $2 \mathrm{~kg}$ ha-i ; when FYM and Azospirillum are applied jointly, $52 ; 16$ and $27 \mathrm{~kg} \mathrm{ha}^{-1}$ of $\mathrm{N}, \mathrm{P}_{2} \mathrm{O}_{5}$ and $\mathrm{K}_{2} \mathrm{O}$ could be reduced from the recommended dose of fertilizers. 


\section{Test verification trials under farmers' holdings}

\section{Grain yield of Rice}

The mean grain yield of rice recorded at the three locations are furnished in Table 5. In all the locations, the highest grain yield was recorded with STCR-IPNS-6 $\mathrm{t} \mathrm{ha}^{-1}$ (5.54 $\mathrm{tha}^{-}$ ${ }^{1}$ ) followed by STCR-IPNS-5 $\mathrm{t} \mathrm{ha}^{-1}\left(4.69 \mathrm{t} \mathrm{ha}^{-1}\right)$. The highest response ratio was recorded in STCR-IPNS-6 t ha ${ }^{-1}\left(7.47 \mathrm{~kg} \mathrm{~kg}^{-1}\right)$ followed by STCR-IPNS-5 $\mathrm{t} \mathrm{ha}^{-1}\left(7.11 \mathrm{~kg} \mathrm{~kg}^{-1}\right)$. The highest B: C ratio was recorded in STCR-IPNS-6 $\mathrm{t} \mathrm{ha}^{-1}$ (1.86). The increase of yield in STCR-IPNS-6 t ha ${ }^{-1}$ was 24.7 per cent over blanket (RDF alone), 21.7 per cent over blanket + FYM and 41.7 per cent over farmers practice. The grain yields recorded under STCR treatments were significantly higher than that under blanket and farmer's practice. The grain yields ranged from $3910 \mathrm{~kg}$ ha- 1 in farmer's practice to $5540 \mathrm{~kg} \mathrm{ha}^{-\mathrm{I}}$ in STCR -IPNS $6 \mathrm{t} \mathrm{ha}^{-\mathrm{I}}$. The increase of yield in STCR-IPNS-6 $\mathrm{t} \mathrm{ha}^{-1}$ was 24.7 per cent over blanket (RDF alone), 21.7 per cent over blanket + FYM and 41.7 per cent over farmers practice. The results revealed that the targeted yield has been achieved within $+/-10$ per cent variation proving the validity of the equations. The favorable influence of organics, inorganics and biofertilizers on chemical, physical and biological properties of soils under IPNS would have resulted in such higher grain yields of rice (Dey, 2016).). The NPK uptake also followed the same trend as that of grain yield.

Table 5. Effect of soil test based fertilization under IPNS for Rice under sodic soil (Mean of three villages)

\begin{tabular}{|c|c|c|c|c|c|c|c|}
\hline \multirow{2}{*}{ Treatments } & \multicolumn{3}{|c|}{\begin{tabular}{|l}
$\begin{array}{l}\text { Fertilizer doses } \\
\text { ha }^{-1} \text { ) }\end{array}$ \\
\end{tabular}} & \multirow{2}{*}{ 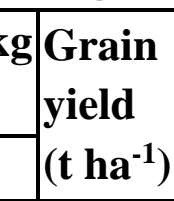 } & \multirow{2}{*}{$\begin{array}{l}\text { Percent } \\
\text { Achieve } \\
\text { ment }\end{array}$} & \multirow{2}{*}{$\begin{array}{l}\mathbf{R R} \quad(\mathrm{kg} \\
\left.\mathrm{kg}^{-1}\right)\end{array}$} & \multirow[t]{2}{*}{ B:C ratio } \\
\hline & $\bar{N}$ & $\overline{\mathrm{P}_{2} \mathrm{O}_{5}}$ & $\mathrm{~K}_{2} \mathrm{O}$ & & & & \\
\hline $\mathrm{T}_{1}-\mathrm{RDF}$ alone & 188 & 50 & 50 & 4.44 & - & 74 & 1.61 \\
\hline $\mathrm{T}_{2}-\mathrm{RDF}+\mathrm{FYM} @ 12.5 \mathrm{t} \mathrm{ha}^{-1}$ & 188 & 50 & 50 & 4.55 & - & 12 & 1.68 \\
\hline $\mathrm{T}_{3}-\mathrm{STCR}-\mathrm{NPK}$ alone $5 \mathrm{t}$ ha & 209 & 45 & 54 & 4.65 & 93.0 & 98 & 1.70 \\
\hline $\mathrm{T}_{4} \mathrm{STCR}-\mathrm{NPK}$ alone $6 \mathrm{t} \mathrm{ha} \mathrm{a}^{-1}$ & 270 & 62 & $75^{*}$ & 5.49 & 91.5 & 35 & 1.73 \\
\hline $\mathrm{T}_{5}-\mathrm{STCR}-\mathrm{IPNS}-5 \mathrm{tha}^{-1}$ & 167 & 27 & $25^{*}$ & 4.69 & 93.8 & 11 & 1.83 \\
\hline $\mathrm{T}_{6}-\mathrm{STCR}-\mathrm{IPNS}-6 \mathrm{t} \mathrm{ha}^{-1}{ }^{*}$ & 228 & 44 & 49 & 5.54 & 92.3 & 47 & 1.86 \\
\hline $\mathrm{T}_{7}-$ Farmers practice & 160 & 35 & 40 & 3.91 & - & 00 & 1.41 \\
\hline $\mathrm{T}_{8}{ }^{-}$Absolute Control & 0 & 0 & 0 & 2.50 & & & 1.09 \\
\hline
\end{tabular}

STCR-IPNS : NPK+12.5 t FYM ha' ${ }^{-1}$ * Maintenance dose 


\section{Per cent achievement}

The highest per cent achievement of the yield targets aimed at were recorded with targeting for $6 \mathrm{t} \mathrm{ha}^{-\mathrm{I}}$ grain yield. Yield targeting with STCR -IPNS recorded relatively higher per cent achievement than that aimed under NPK alone. The per cent achievement of the targets aimed was more than 90 for $6 \mathrm{t} \mathrm{ha}^{-\mathrm{I}}$ yield target under NPK alone and STCR -IPNS indicating the validity of the equations for prescribing fertilizer doses for rice under sodic soil.

\section{Response ratio (RR)}

The mean RR recorded for various treatments ranged from 6.0 in farmer's practice to 7.47 in $6 \mathrm{t} \mathrm{ha}^{-\mathrm{I}}-\mathrm{STCR}$-IPNS. Among the two targets tried, targeting for $6 \mathrm{t} \mathrm{ha}^{\mathrm{I}}$ recorded relatively higher RR than with $5 \mathrm{t} \mathrm{ha}^{-1}$ and it has recorded significantly higher yields. This might be due to the better use efficiency of applied NPK fertilizers at high yield target levels. Likewise, STCR - IPNS treatments recorded higher RR when compared to their respective NPK alone treatments. Blanket recorded 6.74 RR which is lower than STCR treatments. The relatively higher RR recorded under STCR and IPNS treatments when compared to blanket, might be due to balanced supply of nutrients from fertilizer, efficient utilization of applied fertilizer nutrients in the presence of organic sources and the synergistic effect of the conjoint addition of various sources of nutrients (Rao and Srivastava 2000).

\section{Benefit - Cost Ratio (BCR)}

The mean BCR ranged from 1.41 in farmer's practice to 1.86 in $6 \mathrm{t} \mathrm{ha}^{-1}$-STCR IPNS and the trend of results were similar as that of RR. Among the targets aimed, $6 \mathrm{t} \mathrm{ha}^{-1}$ recorded higher BCR over 5 t ha-1. When NPK alone and STCR - IPNS were compared, STCR -IPNS treatments recorded higher BCR (Table 1). In STCR- IPNS technology, the amounts of fertilizer nutrients that are to be applied to obtain any pre-set yield levels are adjusted for the amount of nutrients present in the soil and organic / bio-fertilizers.On account of this adjustment, there is a reduction in the quantity of the nutrients that are to be supplied through fertilizers (Coumaravel, 2012).

\section{Post-harvest soil fertility}

The data on $\mathrm{KMnO}_{4}-\mathrm{N}$, Olsen-P and $\mathrm{NH} 40 \mathrm{Ac}-\mathrm{K}$ indicated the build up and maintenance of soil fertility due to soil test based fertilizer recommendation under IPNS. Despite higherremoval of nutrients, the fertility status ." was maintained at higher level in IPNS as compared to NPK alone. This might be attributed to the prevention of losses of nutrients under IPNS, even after meeting the crop needs. The findings of Velayutham et al (2016) support the results recorded in the present study. It is concluded that for obtaining aimed yield targets and profits with sustenance of soil fertility in Vertisols, soil test based fertilizer recommendation under IPNS could be followed for rice under salt affected soils. 


\section{Summary and conclusion}

It is concluded that for obtaining aimed yield targets and profits with sustenance of soil fertility in salt affected soils, soil test based fertilizer recommendation under IPNS could be followed for rice with suitable reclamation practices. Using the fertilizer prescription equations under IPNS, the extent of saving of inorganic fertilizers was found. i.e with the application of FYM @ $12.5 \mathrm{t} \mathrm{ha}^{-1}$ (with $30 \%$ moisture, $0.60 \%, 0.30$ $\%$ and $0.5 \%$ NPK respectively), there was a saving of 42,18 and $32 \mathrm{~kg}$ of fertilizer $\mathrm{N}$, $\mathrm{P}_{2} \mathrm{O}_{5}$ and $\mathrm{K}_{2} \mathrm{O}$ respectively.

\section{References}

[1] A. Subba Rao and Sanjay Srivastava. "Soil Test Based Fertiliser Use - A must for sustainable agriculture”. Fert. News. 45, 25-38 (2000)

[2] B. Ramamoorthy, R.L. Narsimhan and R.S. Dinesh. "Fertilizer application for specific yield targets of Sonora 64”. Indian Farming 17(5): 43-44. (1967)

[3] R. Ajaykumar, R. Venkitaswamy and A. Rajeshkumar. "Sustainable nutrient management practices to increase the productivity of transplanted low land rice". Cleanup India, TNAU, Coimbatore. (2016).

[4] A. Anjali Basumatary, S.Ahmed and K.N. Das. "Soil test based fertilizer prescriptions under integrated plant nutrient supply for rice-rice cropping sequence in Inceptisol of Assam”. Journal of Indian Society of Soil Science. 63: (2015). 186190.

[5] U. Bagavathi Ammal, R. Sankar, K. Coumaravel and A. Baskar. "Studies on minimizing $N$ fertilizer through STCR-IPNS". In: Proc. International conference on "Conventional or Non-conventional Organic Inputs in Agriculture" Pondicherry, (2013) 209-210.

[6] K. Coumaravel. "Soil Test Crop Response correlation studies through integrated plant nutrition system for maize-tomato sequence”. Ph.D. (Ag.) Thesis, TNAU, Coimbatore. (2012).

[7] M. Velayutham, R. Santhi, R., Subba Rao, A.Muralidharudu and P. Dey. "The Law of Optimum and its application for realizing targeted yields in India-A mini review (Thaninayagam Adigal)":12-20. (2016

[8] P. Dey, P. "Soil Health Management". Bulletin of Indian Society of Soil Science. 13: (2016). 79-97.

[9] B. Ramamoorthy, and M. Velayutham. "The Law of Optimum and soil test base fertilizer use for targeted yield of crops and soil fertility management for sustainable agriculture”. Madras Agricultural Journal. 98: (2011). 295-307.

[10] B. Ramamoorthy, R.L. Narasimham, R.S. Dinesh.. "Fertilizer application for specific yield target of sonara-64 wheat”. Indian Farming, 17:43-45 (1967) 